\title{
DEVELOPMENTS IN SEISMIC DESIGN PROCEDURES FOR BRIDGES IN NEW ZEALAND R Park ${ }^{1}$
}

\begin{abstract}
SUMMARY
Progress on developments in the seismic design procedures for bridges in New Zealand is outlined. The current approach has evolved from the recommendations of a study group of the New Zealand National Society for Earthquake Engineering which was published in 1980. Research and development into the determination of the design seismic force and ductility demand, the capacity design approach, the detailing of bridge columns for adequate ductility, and the design approach using seismic isolation are discussed. More recent developments in New Zealand involving the assessment and retrofit of older bridge structures are also discussed and likely activities and needs of the next decade are suggested.
\end{abstract}

\section{$1 \quad$ INTRODUCTION}

The San Fernando earthquake which occurred in the northern portion of the Los Angeles metropolitan area on 9 February 1971, although only of Richter magnitude 6.6 , caused collapse of many bridge structures in the region of strong ground shaking.

The damaged observed as a result of the San Fernando earthquake was of great interest to New Zealand bridge engineers and triggered considerable research and development into the design of bridge structures for seismic resistance. The former New Zealand National Roads Board had established in 1962 a Road Research Unit. The several Technical Committees of the Road Research Unit had significant research budgets and the Structures Technical Committee encouraged well focused research and development which resulted in several notable developments in bridge seismic design procedures in the 1970s and 1980s in New Zealand. Unfortunately this far sighted research emphasis of the National Roads Board has not been maintained by its successor, Transit New Zealand, who have funded research at a much reduced level.

Again as a consequence of the San Fernando earthquake, in 1978 a discussion group of the New Zealand National Society for Earthquake Engineering was established, bringing together researchers and designers to discuss and appraise procedures for the seismic design of bridges. The extensive report of the discussion group, published in the Bulletin of the New Zealand National Society for Earthquake Engineering in September 1980 [1], consisted of a set of 12 technical papers presented in code and commentary form. The procedures recommended were based on the state of the art and represented good design practice in accordance with the latest developments in earthquake engineering as applied to bridges.

\footnotetext{
${ }^{1}$ Department of Civil Engineering, University of Canterbury (Life Member \& Ex-President).
}

Significant further information on the seismic design of bridges has been published in more recent years in papers in the Bulletin of the New Zealand National Society for Earthquake Engineering and in the papers and summary volumes prepared for Bridge Design and Research Seminars organised by the Road Research Unit of the National Roads Board in Auckland in 1984 [2,3] and more recently by Transit New Zealand in Christchurch in 1990 [4, $5,6,7]$. Also, summaries of New Zealand research and developments have been published in the proceedings of international (Europe/Japan/New Zealand/USA) workshops on the seismic design and retrofitting of reinforced concrete bridges held in 1991 in Bormio, Italy [8] and in 1994 in Queenstown, New Zealand [9]

This paper outlines some background to the developments in the seismic design procedures for bridges in New Zealand, discusses the seismic assessment and retrofit of older bridges, and looks ahead to likely future activities and needs.

\section{BRIDGE DESIGN SPECIFICATIONS IN NEW ZEALAND}

In New Zealand in the 1970s and 1980s the design of highway bridges on public roads, to be financed wholly or partly from funds provided by the former New Zealand National Roads Board, was conducted using various editions of the Highway Bridge Design Brief (for example [10]). The Highway Bridge Design Brief was issued by the former Ministry of Works and Development and specified general design requirements and design loadings. The design of concrete bridges was also required to be in accordance with the concrete design code issued by the Standards Association of New Zealand.

The Highway Bridge Design Brief was replaced in 1989 by a Bridge Manual [11] which was published as a provisional document by the former National Roads Board. When Transit New Zealand replaced the National Roads Board the Bridge Manual was then republished in 1991 as a draft for comment 
entitled Bridge Manual : Design and Evaluation [12]. The final approved version of the Bridge Manual was published by Transit New Zealand in 1994 [13].

The principles of the seismic design approach of the Bridge Manual [13] have evolved from the recommendations of the discussion group of the New Zealand National Society for Earthquake Engineering [1]. The Bridge Manual was prepared for Transit New Zealand by Works Consultancy Services. The seismic design loadings for bridges in the Bridge Manual are based on those recommended in the New Zealand standard for general structural design and design loadings for buildings [14] modified appropriately to apply to bridges. The concrete design is conducted in accordance with the New Zealand concrete design standard [15].

\section{BRIDGE STRUCTURAL SYSTEMS}

A range of highway bridge types are in use in New Zealand. Most bridge superstructures constructed in New Zealand in recent years utilise standard precast prestressed concrete units in the form of I or $\mathrm{T}$ sections, or hollow core or $\mathrm{U}$ or $\mathrm{W}$ sections, or solid rectangular sections, depending on the span. Pretensioned or posttensioned, or combined pre and post-tensioned, concrete units have been used. Generally the precast units act compositely with a cast-in-place reinforced concrete slab or topping. Precast segmental construction has also been used (see Fig. 1). Totally cast-in-place concrete bridge superstructures are more economical and appropriate for long spans, usually continuous, especially where shallow construction depths are necessary, or where the geometric shape of the structure is complicated. Steel superstructures have also been used for longer spans, mainly in the form of modular steel truss form, but also of steel box girder form with composite concrete deck. Superstructure spans are always connected at intermediate supports, either by continuity, by deck linkage slab or by linkage bolts.

The substructures of bridges tend to be constructed of reinforced concrete. A typical bridge substructure may consist of one or more columns, or a wall, supported by either a spread footing or a pile cap connected to driven or cast-in-place piles. At the top of the columns or wall is a cap which supports the superstructure. Sometimes the cap is a diaphragm within a box girder.

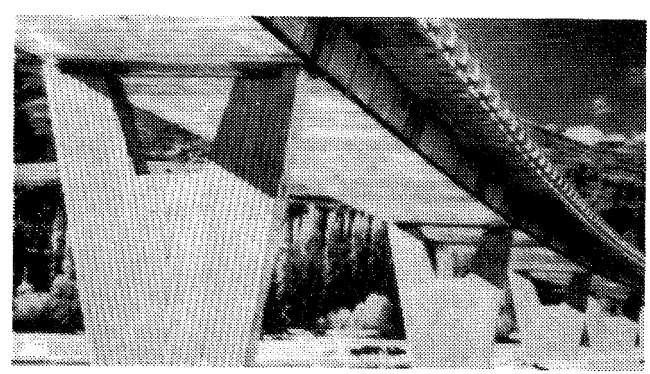

\section{FIGURE I Lower Shotover Bridge Constructed Near Queenstown in the 1970s.}

Recently constructed highway bridge substructures frequently consist of single or multiple steel encased cast-in-place reinforced concrete piles beneath ground level with a reinforced concrete column and column cap above. The end of the bridge superstructure can be designed to be free to rotate and translate relative to the substructure, or designed with integral or semiintegral abutments.

\section{NEW ZEALAND RESEARCH AND DEVELOPMENT INTO THE SEISMIC DESIGN OF BRIDGES}

\subsection{General}

Several significant advances in the procedures for the seismic design of bridges have been developed in New Zealand during the last two decades. The main advances have been in the introduction of more accurately calculated inelastic horizontal acceleration response spectra to relate the design seismic forces to the ductility demand, the capacity design approach for bridge substructures for ensuring that the most appropriate mechanism of post-elastic deformation occurs during a major earthquake, the methods of detailing bridge substructures for adequate ductility, the alternative design approach using seismic isolation and mechanical energy dissipation devices for reducing the seismic response of the bridge, and more advanced methods of structural analysis.

\subsection{Design Seismic Forces and Ductility Demand}

The design horizontal seismic forces were traditionally determined by dividing the elastic horizontal acceleration response spectra by a force reduction factor $\mathrm{R}>1$ to account for the beneficial consequence of the available ductility of the substructure and other effects. This procedure assumed that the maximum horizontal displacement for elastic and inelastic (elastoplastic) structural systems of the same initial fundamental period of vibration $T_{1}$ during a major earthquake were equal. However, Berrill, Priestley and Chapman [16] noted that the equal displacement principle is non-conservative for short period structures where an equal energy approach is more applicable, and that for rigid structures $\left(T_{1}=0\right)$ the design seismic force is independent of the design ductility factor (equal acceleration principle). They proposed that the design horizontal seismic coefficient $C_{h}(T, m)$ for a given displacement ductility factor $m$ could be obtained from the elastic response spectra value $C_{h}(T, 1)$ as follows:

For $T_{1}>0.7$ seconds, the equal displacement principle is applied, namely:

$$
\mathrm{C}_{\mathrm{h}}(\mathrm{T}, \mu)=\frac{\mathrm{C}_{\mathrm{h}}(\mathrm{T}, 1)}{\mu}
$$

For $T_{1}<0.7$, the following empirical equation is used, namely:

$$
\mathrm{C}_{\mathrm{h}}(\mathrm{T}, \mu)=\frac{\mathrm{C}_{\mathrm{h}}(\mathrm{T}, 1)}{\frac{(\mu-1) \mathrm{T}_{1}+1}{0.7}}
$$

Eq. 2 gives a linear variation in the force reduction factor $\mathrm{R}$ from

$\mathrm{R}=1$ at $\mathrm{T}_{1}=0$ to $\mathrm{R}=\mu$ at $\mathrm{T}_{1}=0.7$ seconds, passing through the equal energy value at an intermediate value for $T_{1}$.

This more realistic determination of the design seismic forces for short period structures was a significant step forward. A similar approach has been used for the inelastic spectra recommended in NZS 4203:1992 [14] (see Fig. 2). In NZS 4203:1992, Eq. 2 is used for the period range $0.45 \leq T_{1} \leq 0.7$ seconds for rock or very 
stiff soils and for intermediate soils, and for the period range $0.6 \leq$ $\mathrm{T}_{1} \leq 0.7$ seconds for flexible or deep soils. Below those minimum values for $T_{1}$ the value of $C_{h}(T, \mu)$ is held constant in order to allow for the adverse effects of the reduction in stiffness due to cyclic loading of initially very stiff structures.

Also, the new Applied Technology Council provisional recommendations, ATC-32 [17], published in 1996, has force reduction factors for full ductility and limited ductility structures which over a low period range decrease linearly to reach a value of unity when $T_{1}=0$. The new Japanese bridge code approved by the Ministry of Construction in 1996 still uses the equal energy principle for all periods of vibration and hence the force reduction factor from the assumed elastic spectra is $\sqrt{ }(2 \mu-1)$ for all values of $T_{1}$.

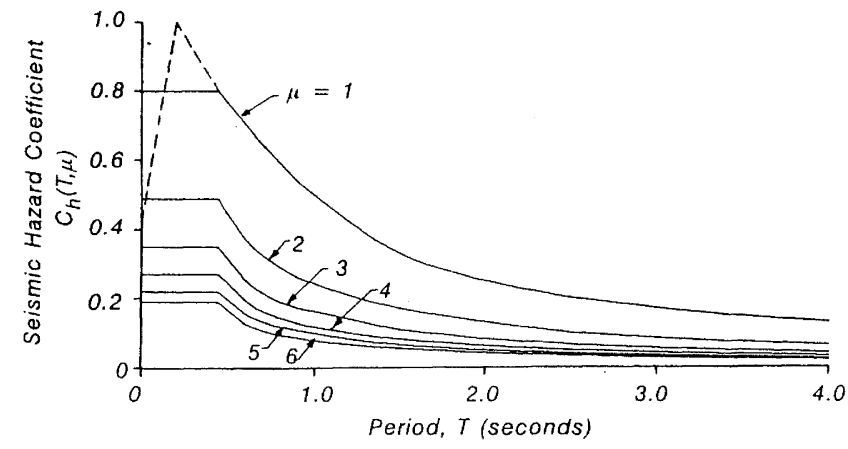

FIGURE 2 Seismic Hazard Coefficients for Design Horizontal Seismic Forces for Intermediate Soil Sites[14]

\subsection{The Capacity Design Approach}

The capacity design approach was first introduced for buildings by Hollings in 1969 [18]. Park and Paulay in 1975 [19] defined the capacity design procedure as follows:

In the capacity design of earthquake-resistant structures, energydissipating elements of mechanisms are chosen and suitably detailed, and other structural elements are provided with sufficient reserve strength capacity, to ensure that the chosen energy-dissipating mechanisms are maintained at near their full strength throughout the deformations that may occur.

In the capacity design approach for bridge substructures the desired location of plastic hinges when a mechanism develops during a major earthquake is chosen by the designer. The design flexural strengths of the plastic hinges are made adequate to match the bending moments and axial loads imposed by the design seismic plus gravity forces. Then the overstrength flexural capacities of the plastic hinges are calculated from:

\section{Overstrength flexural capacity \\ $=\phi_{0} \times$ design flexural strength}

where $\phi_{0}=$ flexural overstrength factor $>1.0$ to take into account factors such as higher than specified strengths of steel and concrete, steel strain hardening, confinement of concrete, and the use of a strength reduction factor to obtain the design flexural strength from the nominal value.

The overstrength flexural capacities at the plastic hinge regions are used to calculate the design shear forces at the plastic hinge regions and the design bending moments and shear forces elsewhere in the structure, and the sections are designed for those actions. As a result, plastic hinges should not form at regions away from the selected locations and shear failures should not occur anywhere.

In New Zealand the flexural overstrength factor for columns with $\mathrm{N}^{*} / \mathrm{f}_{\mathrm{c}}^{\prime} \mathrm{A}_{\mathrm{g}} \leq 0.1$, where $\mathrm{N}^{*}=$ axial compressive load on column, $\mathrm{f}_{\mathrm{c}}$ $=$ specified concrete compressive cylinder strength and $A_{g}=$ gross area of the column, is taken to be $\phi_{0}=1.25 / 0.85=1.47$, since the overstrength of the steel is taken as $1.25 \mathrm{f}_{\mathrm{y}}$. where $\mathrm{f}_{\mathrm{y}}$ is the lower characteristic yield strength and the strength reduction factor for flexure is 0.85 . The overstrength factor for reinforcing steel of 1.25 was confirmed by extensive statistical analysis of the measured stress-strain characteristics of New Zealand manufactured reinforcing steel by Andriono and Park [20]

For columns with $\mathrm{N}^{*} / \mathrm{f}_{\mathrm{c}} \mathrm{A}_{\mathrm{g}}>0.1$ it has been shown that the effect of concrete confinement should aiso be included. The values for the flexural overstrength factor including the effect of confinement $(>1.47)$ can be taken as analytically determined by Zahn et al [21] or as experimentally determined by Ang et al [22].

The need for a capacity design approach was again illustrated by the collapse of bridge structures during the 1995 earthquake in Kobe, Japan as a result of brittle shear failures, including shear failures at regions of premature cut-off of longitudinal reinforcement as a result of unintended plastic hinging there. However, the new Japanese bridge code that was approved by the Ministry of Construction in 1996 still does not require a capacity design procedure to avoid shear failures.

\subsection{The Detailing of Bridge Columns for Adequate Ductility}

A major change in the detailing provisions of reinforced concrete columns since the 1970s is the provision of significant quantities of transverse reinforcement in potential plastic hinge regions. Transverse reinforcement is required to confine the compressed concrete, to prevent premature buckling of longitudinal compression reinforcement, and to prevent shear failure. The potential plastic hinge regions of bridge substructures need to be carefully detailed to ensure that the plastic rotations occurring in the chosen plastic mechanism, as a result of the deformations reached during the design ultimate limit state earthquake, can be sustained.

More than 50 reinforced concrete columns of various cross sectional shape, including solid and hollow, have been tested subjected to simulated seismic loading at the University of Canterbury in a 1000 tonne DARTEC universal testing machine, which was purchased with part support from the Road Research Unit in 1978. These tests permitted the stress-strain characteristics of confined concrete to be determined (see Fig. 3) and enabled column performance to be computed analytically and confirmed experimentally $[2,4,21,22,23]$. In particular the analytical work led to methods for calculating the quantities of confining reinforcement required to achieve specified plastic hinge rotations $[24,25]$. It was found that the required quantity of transverse reinforcement was a function of several column variables. For example the required quantity increased with increase in axial load ratio $\mathrm{N}^{*} / \mathrm{f}_{\mathrm{c}} \cdot \mathrm{A}_{\mathrm{g}}$ as well as with increase in curvature ductility demand. Also, detailing rules for transverse reinforcement in the plastic hinge regions of columns were determined with regard to the vertical and horizontal spacing of transverse reinforcement required for effective confinement of the concrete and to prevent premature buckling of the compressed longitudinal bars. In 
addition, the length of the plastic hinge region of the column to be confined was found to depend on the axial load on the column and the gradient of the moment diagram.

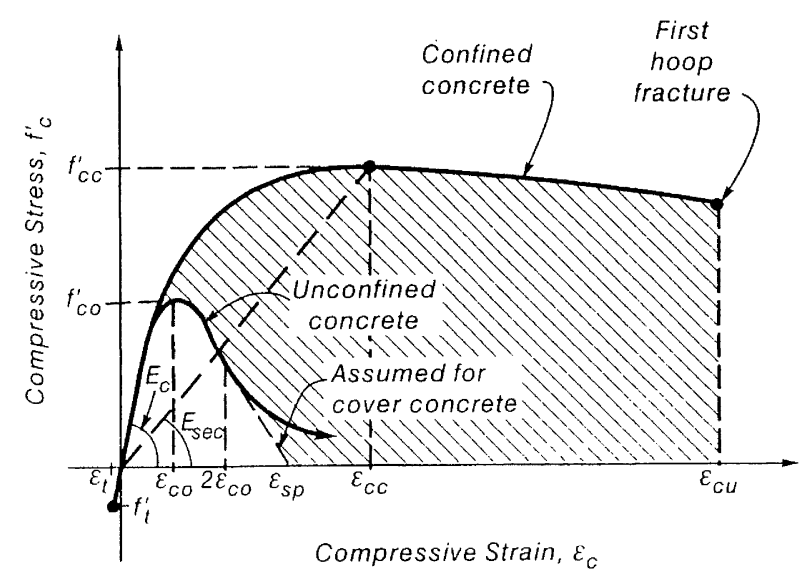

FIGURE 3 Typical Compressive Stress-Strain Curves for Unconfined and Confined Concrete [23]

The recommended approach for designing bridge substructures for adequate ductility is to determine the required curvature ductility factor associated with the chosen plastic mechanism by static push-over analysis (or dynamic analysis). Then sufficient transverse reinforcement is provided for the column plastic hinge regions to achieve that curvature ductility factor demand $[2,23$, 24]. The transverse reinforcement is also checked to ensure that it is adequate for the prevention of buckling of longitudinal compression reinforcement and to prevent shear failure.

\subsection{The Design Approach Using Seismic Isolation and Mechanical Energy Dissipating Devices}

New Zealand has also been a world leader in the development of seismic isolation and mechanical energy dissipating devices for the protection of structures against earthquakes [26]. For bridge structures this design procedure provides an alternative to the ductile design approach. Seismic isolation is achieved by mounting structures on rubber bearings, or flexible isolated piles. This increases the fundamental period of vibration of the structure so that it moves away from the predominant period of earthquake ground shaking, thus lessening the effects of earthquake ground shaking on the structure. The mechanical energy dissipating devices are in the form of lead plugs in the rubber bearings, or steel attachments or lead extrusion devices, which in bridge structures are generally placed between the bridge deck and the top of the piers and deform inelastically during severe earthquakes. Their function is to increase the damping of the structure. The lead-rubber bearing is particularly well known and used internationally. It has the advantage of combining the functions of base isolation and energy dissipation in the bearing unit. A range of energy dissipating devices is shown in Fig. 4. A major benefit of using seismic isolation and mechanical energy dissipating devices is that damage to the structure in major earthquakes can be reduced or even eliminated.
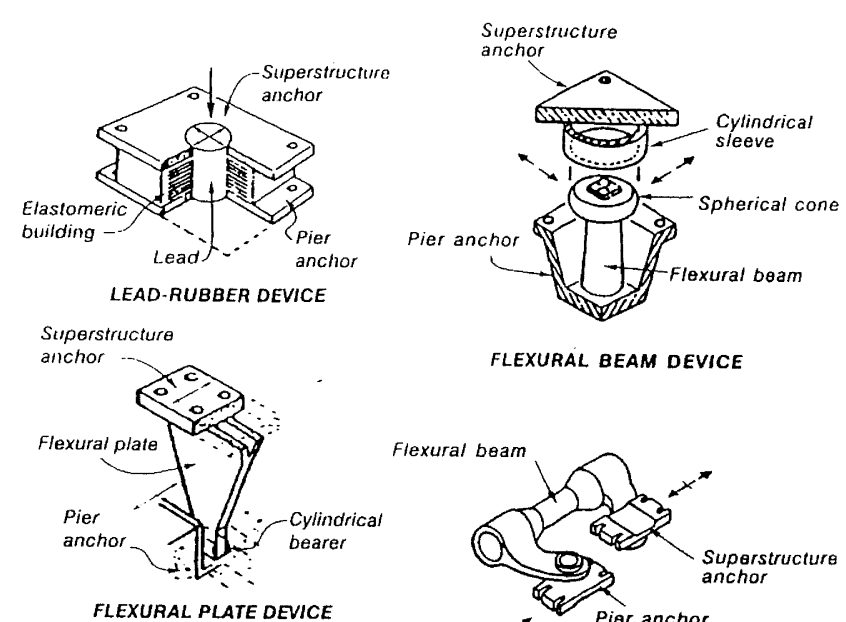

FLEXURAL BEAM DEVICE

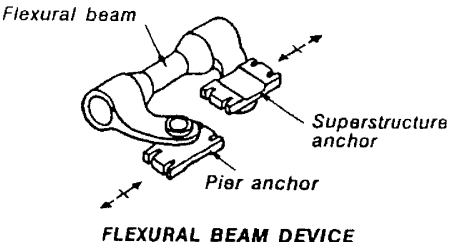

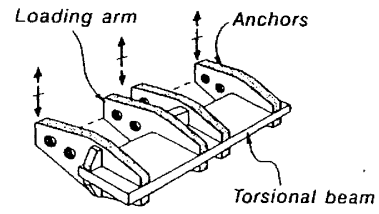

TORSIONAL BEAM DEVICE

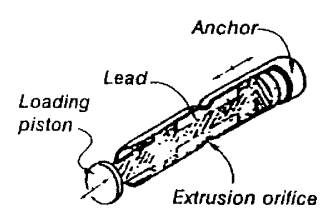

LEAD EXTRUSION DEVICE

\section{FIGURE 4 Mechanical Energy Dissipating Devices Devised by DSIR, New Zealand}

The pioneering work on seismic isolation conducted at the DSIR laboratories, Gracefield commenced in 1968 [26]. The first bridge to be seismically isolated in New Zealand was the Motu bridge in 1973, which used steel in flexure for damping. According to Robinson [27], up to 1995 in New Zealand a total of 50 road and rail bridges have been seismically isolated. Table 1 shows a table prepared by Robinson [27] comparing the number of bridges with seismic isolation devices constructed in New Zealand, Japan, USA and Italy.

TABLE 1: Applications of Seismic Isolation Devices to Bridges in New Zealand, Japan, USA and Italy [27]

\begin{tabular}{||l|l|}
\hline Year/Country & $\begin{array}{l}\text { Damping } \\
\text { System(s) }\end{array}$ \\
\hline 1974 to 1985: & \\
New Zealand & $\begin{array}{l}19 \text { LRB, 2 LED, } 4 \\
\text { Steel. } \\
19 \text { Elastomeric, 9 } \\
\text { Viscous. }\end{array}$ \\
Italy & \\
\hline 1985 to 1995: & 21 LRB, 1 LRB + \\
New Zealand & LED, 3 Steel. \\
& 19 LRB, 4 \\
Japan & Elastomeric. \\
& 81 LRB. \\
USA & 6 LRB, 75 Steel, \\
Italy & 29 Viscous, 14 \\
& Elastomeric. \\
\hline
\end{tabular}


Key: $\mathrm{LRB}=$ Lead rubber bearing LED = Lead extrusion damper; Steel includes steel cantilevers, beams, etc, undergoing plastic deformation; Elastomeric includes Rubber and Neoprene bearings.

Only one seismically isolated bridge in New Zealand has been subjected to the effect of a large earthquake to date, namely the Te Teko bridge over the Rangitaika river during the 1987 Edgecumbe earthquake. The performance was adequate but one of the elastomeric bearings was not adequately restrained against sliding and moved out of position.

\subsection{Structural Analysis Techniques}

Progress in the development of analytical procedures for the seismic design of bridges has been substantially assisted in New Zealand by the availability of the computer programme RUAUMOKO [28]. RUAUMOKO is capable of time history nonlinear dynamic analysis of structures and has been widely used in research into the seismic response of bridges, as well as buildings, in New Zealand and overseas. It is also available to design offices.

\section{ASSESSMENT AND RETROFITTING OF EXISTING BRIDGES}

In 1991 Chapman [9] estimated that New Zealand's stock of highway bridges with spans exceeding $3 \mathrm{~m}$ comprised approximately 2,500 structures on state highways and approximately 8,000 on local authority highways. Of the state highway stock, about $70 \%$ was built in the period 1930 to 1970 and $20 \%$ was built since 1970 . Hence much of New Zealand's stock of highway bridges was built before 1970 and therefore has not been deliberately designed using capacity design principles nor intentionally detailed for ductility. Also, the connecting linkages between simple spans of those bridges may be inadequate.

Experience overseas of poor performance of bridges in recent earthquakes, for example the 1989 Loma Prieta and the 1994 Northridge earthquakes in California, and the 1995 Great Hanshin earthquake in Kobe, Japan, has emphasised the deficiencies of some of the older bridge stock and of the importance of carrying out seismic assessment and retrofitting where necessary.

As part of lifelines studies of transportation networks some local authorities in New Zealand have identified bridges in need of retrofit and some necessary upgrading has commenced. For example, Aotea Quay Overbridge in Wellington, which was constructed in 1937 and spans over the Hutt Road and all railway lines leading into Wellington, has recently been retrofitted [29]. Part of the retrofit involved enclosing existing columns with jackets of high strength fibre/expoxy composites. Also, the $1.3 \mathrm{~km}$ long Thorndon overbridge, which carries motorway traffic over railway and harbour facilities in Wellington, and which was completed in 1969, has recently been assessed and has been shown to need seismic upgrading. The retrofitting of a number of piers of the Thorndon overbridge, which is about to be conducted, will involve enclosing the existing circular reinforced concrete columns with grouted thin steel jackets and casting an overlay of new reinforced concrete over the existing pile caps [30,31] (see Fig. 5). Also, the connecting linkages between the spans will be improved.
A preliminary screening procedure [32] for seismic assessment recently developed by Works Consultancy Services has been trialled by Transit New Zealand to identify bridges which are in need of retrofitting. The proposed procedure [32] is based on the model developed

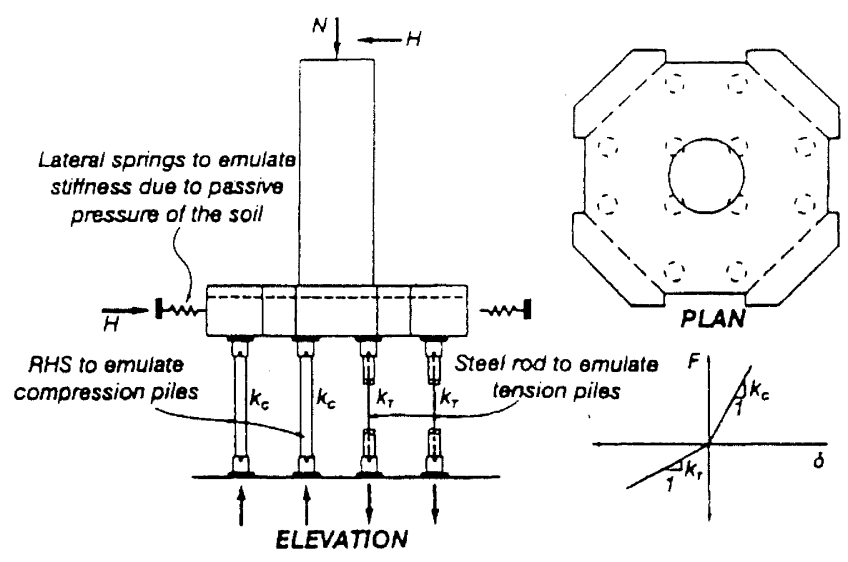

(a) Loading arrangement showing tension and compression springs simulating piles.

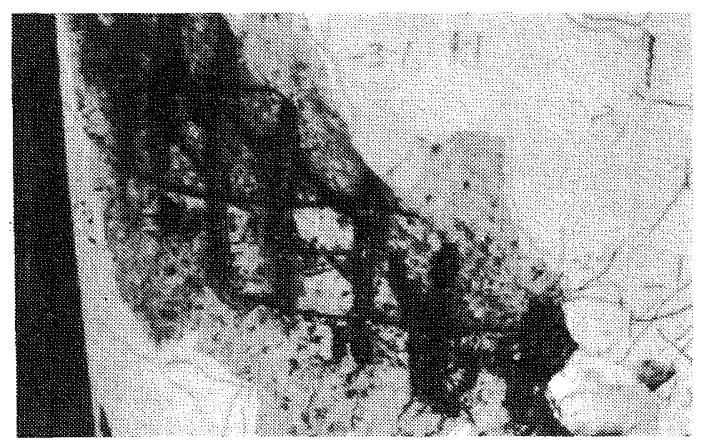

(b) Shear failure of pier column at section of cut-off of longitudinal reinforcement at mid-height of column due to unintended plastic hinging there.

\section{FIGURE 5 Testing of a $1 / 3.8$ Scale Model of the Column/Pile Cap/Pile Region of a Pier of the Thorndon Overbridge [31]}

by the State of California Department of Transportation (Caltrans). The details of the Caltrans procedure and commentary on its development are described by Gilbert [33]. The procedure has three main parts:

Identification of bridges with a low risk of catastrophic collapse during a severe earthquake, so that they can be excluded from further assessment.

Identification of bridges which lack positive connecting linkages between the superstructure elements, so that they can be assessed as soon as possible for possible retrofit

Screening of bridges not in the above two categories to evaluate: 
- Hazard (seismicity of bridge site and other hazards threatening the bridge).

- Importance of the bridge.

- Vulnerability of the structural system.

The pilot application of the preliminary screening procedure considered 29 bridges on State Highway 1 between Bulls and Wellington, North Island [32].

Research work at the University of Canterbury [34] has also resulted in a screening procedure for seismic assessment. This work questions a number of aspects of the Caltrans procedures, such as the multiplicative seismic factors and the additive combinations which may make the procedure insensitive to major changes in important variables. Other research work at the University of Canterbury $[34,35]$ has involved simulated seismic load tests on replicas of subassemblages of existing New Zealand reinforced concrete bridges, which has determined deficiencies due to poor anchorage of reinforcement, particularly of plain round longitudinal bars, and inadequate quantities of transverse reinforcement.

\section{FUTURE ACTIVITIES AND NEEDS}

Activities in New Zealand during the next decade with regard to bridging are certain to concentrate mainly on the seismic assessment of the countries stock of pre-1970s bridges and the retrofit where necessary. This will need an agreed preliminary screening procedure, a more detailed assessment procedure for use where necessary, and a catalogue of retrofit methods. There is a need to establish a new study group of the New Zealand National Society for Earthquake Engineers to assess the state of the art in bridge seismic assessment and retrofit. A number of issues need resolution. For example, how to score various bridge deficiencies in a preliminary assessment procedure needs further discussion. A great deal of experience of bridge seismic assessment and retrofit is now available in California and Japan as a result of upgrading, or repair and upgrading after earthquakes, during the last decade, and this experience can be drawn on. Further research and development into the assessment and retrofit options in New Zealand is needed. Transit New Zealand needs to be informed of the need for more consideration of the assessment and retrofit, where necessary, of New Zealand's pre-1970s bridge stock. The task ahead may be large. In 1986, a survey of Japan's bridges found that $30 \%$ required some form of retrofitting; in California it was found that as at May 1994 about $24 \%$ of the state highway bridges were vulnerable to collapse [34].

There are several other topics which no doubt will be exercising the minds of code writers and designers of bridges in the future. One is the merits of using a displacement-based approach for seismic design rather than the force-based approach which is currently used. It has been said that the weakness of the forcebased approach is the assumed relation between elastic and inelastic acceleration response spectra for various displacement ductility factors and the emphasis on strength. In a displacementbased approach the comparison of demand and capacity is in terms of displacements found from displacement response spectra for different levels of equivalent viscous damping. There is no doubt that the displacement-based approach is more logical.

Some other topics for further future consideration are the relative merits of strong and stiff piers versus less strong and less stiff piers, the use of interlocking spirals or helices for transverse reinforcement, and analytical techniques for bridges with various unsymmetrical pier arrangements and curved decks. The results of analysis obviously depend on the assumptions made and some computer programs may not model inelastic behaviour well. Comparisons of some results of bridge seismic analyses conducted in different countries have shown interesting differences [9].

There is also no doubt that more use will be made of seismic isolation and mechanical energy dissipating devices in the future, both for new bridges and for retrofitting. As a result of bridge damage during the earthquake in Kobe in 1995, Japanese bridge engineers are moving more towards the use of seismic isolation and mechanical energy dissipating techniques.

The recent book by Priestley et al [36] contains the most up to date information on the seismic design of bridges, including the capacity design and ductile detailing of bridges, and of retrofitting. This book is based on research conducted in New Zealand, the USA and elsewhere and is a major reference source for practising designers, researchers and senior students.

\section{CONCLUSIONS}

Rapid advances in the development of seismic design procedures for bridges have occurred in New Zealand during the 1970s and 1980 s. This work was triggered by the significant damage to bridges caused by the San Fernando earthquake in California in 1971. The current procedures for the seismic design of bridge structures evolved from the report of the study group of the New Zealand National Society for Earthquake Engineering which was published in 1980. Significant developments in New Zealand have been the inelastic spectra used to determine the design seismic forces as a function of structure ductility factor, the capacity design approach, the methods for detailing of bridge substructures for adequate ductility, the design approach using seismic isolation and mechanical energy dissipating devices, and advanced methods of structural analysis. A main need for the future is the seismic assessment, and retrofitting where necessary, of New Zealand's pre-1970s bridge stock. Transit New Zealand should be made more aware of this need and a study group of the New Zealand National Society for Earthquake Engineering established to assess the state of the art of bridge seismic assessment and retrofit.

\section{ACKNOWLEDGEMENTS}

The financial support and encouragement of the Road Research Unit of the former New Zealand National Roads Board in the 1970s and 1980s is acknowleged. That support enabled considerable well focused research and development into the seismic design of bridges during that period in New Zealand which resulted in significant developments in bridge seismic design procedures. The efforts of the NZNSEE discussion group, chaired by Mr JBS Huizing, that produced the state of the art report on the seismic design of bridges in 1980 [1] are acknowledged.

\section{REFERENCES}

$1 \quad$ NZNSEE Discussion Group (1980), Papers Resulting From the Deliberation of the Society's Discussion Group on the Seismic Design of Bridges, Sections 1 to 12, Vol. 13., No. 3, pp 226-309. 
2 Priestley MJN and Park, R (1984). Strength and Ductility of Bridge Structures, RRU Bulletin 71, National Roads Board, Wellington (see also Priestley MJN and Park R (1987), Strength and Ductility of Concrete Bridge Columns Under Seismic Loading, Structural Journal of the American Concrete Institute, Vol. 84, No. 1, pp 61-76).

3 Technical Papers (1984), Bridge Design and Research Seminar, RRU Bulletin 73, National Roads Board, Wellington.

4 Park, R and Paulay, T (1990), Strength and Ductility of Concrete Substructures of Bridges, RRU Bulletin 84, Volume 1, Transit New Zealand, Wellington.

5 Wood J H and Elms D G (1990), Seismic Design of Bridge Abutments and Retaining Walls, RRU Bulletin 84, Volume 2, Transit New Zealand, Wellington.

6 Chapman H E and Kirkcaldie, D K (1990), Seismic Design of Base Isolated Bridges Incorporating Mechanical Energy Dissipators, RRU Bulletin 84, Volume 3, Transit New Zealand, Wellington.

7 Summary Papers and Other Technical Papers (1990), Bridge Design and Research Seminar, RRU Bulletin 84, Volume 5, Transit New Zealand, Wellington.

8 Proceedings (1991), International Workshop on the Seismic Design and Retrofitting of Reinforced Concrete Bridges, Bormio, Italy.

9 Proceedings (1994), International Workshop on the Seismic Design and Retrofitting of Reinforced Concrete Bridges, Queenstown, New Zealand.

10 Ministry of Works and Development (1978), Highway Bridge Design Brief, Wellington.

11 National Roads Board (1989), Bridge Manual (Provisional), Wellington.

12 Transit New Zealand (1991), Bridge Manual : Design and Evaluation (Draft for Comment), Wellington.

13 Transit New Zealand (1994), Bridge Manual plus amendment No. 1 June 1995, Wellington.

14 Standards New Zealand (1992), General Structural Design and Design Loadings for Buildings, NZS 4203:1992, Wellington.

15 Standards New Zealand (1995), Design of Concrete Structures, NZS 3101:1995, Wellington.

16 Berrill J B, Priestley MJN and Chapman H E (1980), Design Earthquake Loading and Ductility Demand, Section 2 of Reference 1.

17 Applied Technology Council (1996), Improved Seismic Design Criteria for Californian Bridges : Provisional Recommendations, ATC 32, Redwood City, California.
18 Hollings J P (1969) Reinforced Concrete Seismic Design, Bulletin of the New Zealand Society for Earthquake Engineering, Vol. 3, No. 2, pp 217-250.

19 Park R and Paulay T (1975), Reinforced Concrete Structures, John Wiley, New York.

20 Andriono, $\mathrm{T}$ and Park R (1986), Seismic Design Considerations of the Properties of New Zealand Manufactured Reinforcing Bars, Bulletin of New Zealand National Society for Earthquake Engineering, Vol. 19, No. 3, pp 213-246.

21 Zahn F A, Park R and Priestley, MJN (1986), Design of Bridge Columns for Strength and Ductility, Research Report 86-7, Department of Civil Engineering, University of Canterbury.

22 Ang Beng Ghee, Priestley MN and Paulay T (1985), Seismic Shear Strength of Circular Bridge Columns, Research Report 85-5, Department of Civil Engineering, University of Canterbury.

23 Mander J B, Priestley MJN and Park R, (1984), Seismic Design of Bridge Piers, Research Report 84-2, Department of Civil Engineering, University of Canterbury.

24 Zahn F A, Park R, Priestley MJN and Chapman H E (1986), Development of Design Procedures for the Flexural Strength and Ductility of Reinforced Concrete Bridge Columns, Bulletin of New Zealand National Society for Earthquake Engineering, Vol. 19, No. 3, pp 200-212.

25 Watson S, Zahn F A and Park R, (1994), Confining Reinforcement for Concrete Columns, Journal of Structural Engineering, American Society of Civil Engineers, Vol. 120, No. 6, pp 1798-1824.

26 Skinner R I, Robinson W H and McVerry G (1993), An Introduction to Seismic Isolation, John Wiley, Chichester.

27 Robinson W H (1995), Recent Research and Applications of Seismic Isolation in New Zealand, Bulletin of the New Zealand National Society for Earthquake Engineering, Vol. 28, No. 4, pp 253-264.

28 Carr A J (1994), RUAUMOKO Users Guide, Department of Civil Engineering, University of Canterbury.

29 Grey A D and White B (1997), Aotea Quay Overbridge, Wellington Seismic Retrofit, Proceedings of Annual Conference of the Institution of Professional Engineers New Zealand, Vol. 1, Wellington, pp 95-109.

30 Powell A J (1997), Thorndon Overbridge Seismic Retrofit, Proceedings of Annual Conference of the Institution of Professional Engineers New Zealand, Vol. 1, Wellington, pp 90-94.

31 Presland R, Restrepo J I and Park R (1996), Laboratory Testing of the Proposed Thorndon Overbridge Retrofit Structures, Proceedings of Annual Conference of the New Zealand Concrete Society, Wairakei, pp 93-102. 
32 Works Consultancy Services Ltd (1996), Seismic Assessment of New Zealand Highway Bridges:

Development and Testing of Preliminary Screening Procedures, Research Report No. 58, Transit New Zealand, Wellington.

33 Gilbert A D (1993), Developments in Seismic Prioritisation of Bridges in California, California Department of Transportation Division of Structures, Internal Summary Document, Sacramento.

34 Maffei J and Park R (1996) The Seismic Evaluation and Retrofitting of Bridges, Research Report 96-2, Department of Civil Engineering, University of Canterbury.

35 Park R, Rodriguez M and Dekker D R (1993), Assessment and Retrofit of a Reinforced Concrete Bridge Pier for Seismic Resistance, Earthquake Spectra, Professional Journal of the Earthquake Engineering Research Institute, Vol. 9, No. 4, pp 781-801.

36 Priestley MJN, Seible F and Calvi C M (1996), Seismic Design and Retrofit of Bridges, John Wiley and Sons, New York. 